\title{
Kombinasi Ekstender Larutan Sari Kurma (Phoenix dactylifera) dan Ringer Laktat dalam Kualitas Spermatozoa Beberapa Ikan Air Tawar
}

\section{Extender Combination of Date Palm Juice (Phoenix dactylifera) and Lactatic Ringer on Spermatozoa Quality of Freshwater Fish}

\author{
Fani Fariedah ${ }^{1^{*}}$ dan Maheno Sri Widodo ${ }^{1}$
}

${ }^{1}$ Program Studi Budidaya Perairan, Jurusan Manajemen Sumbedaya Perairan, Fakultas Perikanan dan Ilmu Kelautan, Universitas Brawijaya, Jl. Veteran, Malang 65141, Indonesia

*Correspondence :

fanifariedah@ub.ac.id

Received : 2019-11-06

Accepted : 2020-05-29

Kata Kunci :

Larutan sari kurma, Ringer laktat, Ekstender, Spermatozoa, Ikan air tawar

Keywords :

Date palm solution, Ringer lactatic, Extender, Spermatozoa, Freshwater fish

\begin{abstract}
Abstrak
Penelitian ini bertujuan untuk mengetahui pengaruh kombinasi larutan ekstender kurma dan ringer laktat terhadap kualitas spermatozoa beberapa ikan air tawar dalam proses pengawetan spermatozoa. Proses pengawetan sperma tergantung pada nutrisi yang disediakan oleh bahan ekstender. Ringer laktat telah digunakan sebagai ekstender dalam proses pengawetan sperma yang berguna sebagai penyedia energi. Energi lain dapat diperoleh dari bahan yang mengandung fruktosa atau glukosa. Sari kurma merupakan salah satu bahan yang memiliki kandungan fruktosa dan glukosa yang diharapkan dapat membantu memberikan energi bagi sperma selama proses pengawetan sperma. Penelitian ini melakukan percobaan pengawetan sperma dari beberapa ikan air tawar ikan mas (Carassius auratus), ikan lele siam (Pangasius hypophthalmus), dan Koi (Cyprinus carpio) menggunakan ekstender yang dibuat dalam kombinasi dari ringer laktat dan larutan sari kurma. Penelitian ini menggunakan berbagai konsentrasi ekstrak kurma yaitu 0,5\%, $1 \%, 2,5 \%, 2 \%$ menggunakan desain rancangan acak kelompok dengan ikan sebagai kelompok. Hasil penelitian menunjukkan bahwa rata-rata motilitas ikan patin mencapai nilai tertinggi $(52,00 \%)$ sedangkan rata-rata laju fertilisasi tertinggi terjadi pada spermatozoa ikan mas dengan nilai 97,06\%. Larutan sari kurma mampu memberikan nutrisi pada spermatozoa selama proses pengawetan karena kurma mengandung fruktosa dan glukosa sehingga spermatozoa yang diawetkan tetap dapat membuahi secara normal.
\end{abstract}

\section{Abstract}

This study aims to determine the effect of the extender combination of dates and ringer lactate extracts on the quality of spermatozoa of some freshwater fish in the process of preserving spermatozoa. The process of sperm preservation depends on the nutrients provided by the extender material. 
Ringer lactate has been used as an extender in the process of preserving sperm which is useful as an energy provider. Other energy can be obtained from materials that contain fructose or glucose. Date palm juice is one ingredient that has a fructose and glucose content that is expected to help provide energy for sperm during the process of sperm preservation. In this study an experiment of sperm preservation of several freshwater fishes carp (Carassius auratus), Siamese catfish (Pangasius hypophthalmus), and Koi (Cyprinus carpio) using an extender made in combination from ringer lactate and date palm solution. This study used different concentrations of date extracts i.e. $0.5 \%, 1 \%, 2.5 \%, 2 \%$ used randomized group design with fish as group. The results showed that the average of the Siamese's motility achieved the highest value $(52,00 \%)$ while the highest average fertilization rate occurred on Carp spermatozoa with a value of $97,06 \%$. Palm juice solution can provide nutrients to the spermatozoa during the preservation process because the juice of dates contains fructose and glucose so that preserved spermatozoa can still fertilize normally.

\section{PENDAHULUAN}

Permasalahan yang terjadi pada pemijahan ikan, baik secara alami dan buatan adalah pematangan gamet yang kadang tidak terjadi secara bersamaan. Hal tersebut secara langsung berpengaruh pada ketersediaan benih di kalangan pembudidaya baik ikan hias maupun ikan konsumsi. Permasalahan tersebut selama ini dapat dipecahkan melalui teknik pengawetan sperma dengan menyimpan pada suhu dingin untuk mempertahankan kualitas sperma dengan didukung bahan yang dapat mempertahankan kehidupan dan mengurangi aktivitas spermatozoa. Menurut Salisbury et al. (1985), energi yang dibutuhkan oleh spermatozoa disediakan oleh gula sederhana (monosakarida) seperti fruktosa dan glukosa. Salah satu bahan yang memenuhi kriteria sebagai bahan tambahan dalam larutan pengencer sperma adalah sari kurma (Phoenix dactylifera).

Widyaningsih (2016) sebelumnya telah melakukan penelitian tentang penggunaan larutan sari kurma terhadap viabilitas dan motilitas spermatozoa ikan nilem (Oseteocilus hasseltii Valenciennes), namun belum ada informasi penggunaan larutan sari kurma pada proses pengawetan spermatozoa ikan mas, ikan lele, dan ikan koi, sehingga perlu dilakukan penelitian tentang penggunaan larutan sari kurma pada proses pengawetan spermatozoa ikan mas, ikan lele, dan ikan koi.

Prinsip kerja pengawetan sperma pada dasarnya adalah pengenceran dan penyimpanan pada suhu dingin. Dalam hal ini membutuhkan bahan yang dapat mempertahankan kehidupan dan mengurangi aktivitas spermatozoa. Menurut Salisbury et al. (1985), penambahan fruktosa atau glukosa dalam pengencer berguna untuk mendukung proses pembentukan Adenosine Triphosphate (ATP) dan Adenosine Diphosphate (ADP) yang harus berlangsung. Selain itu, media penyimpanan harus mampu memberikan sifat penyangga (buffer) dan dapat melindungi sperma terhadap cold shock agar keadaan sperma tetap stabil. Salah satu bahan yang memenuhi kriteria sebagai bahan tambahan dalam larutan pengencer sperma adalah sari kurma (Phoenix dactylifera).

Menurut Retnowati dan Kusnadi (2013), buah kurma mengandung komponen yang sebagian besar merupakan gula pereduksi, yaitu glukosa 
dan fruktosa 20-70\% (bobot kering) sehingga dapat digunakan sebagai sumber energi pada sperma untuk tetap bertahan hidup pada larutan pengencer.

Penelitian ini bertujuan untuk mengetahui pengaruh ekstender kombinasi larutan sari kurma dan ringer laktat terhadap kualitas spermatozoa beberapa ikan air tawar dalam proses pengawetan spermatozoa.

\section{METODOLOGI}

\section{Waktu dan Tempat}

Penelitian ini dilaksanakan di Fakultas Perikanan dan Kelautan Universitas Brawijaya.

\section{Materi Penelitian}

Alat-alat yang digunakan dalam penelitian ini adalah mikroskop binokuler, gelas objek, gelas penutup, termometer $\mathrm{Hg}$, beaker glass $250 \mathrm{ml}$, spuit $1 \mathrm{ml}$, handtally counter, timbangan digital analitik, gelas ukur, lap basah, micropipette, haemocytometer, ember plastik, aerator set, $\mathrm{pH}$ paper, nampan, heater, lemari pendingin (suhu $5^{\circ} \mathrm{C}$ ), inkubator, kolam, bulu ayam, seser, dan rak microtube.

Bahan- bahan yang digunakan dalam penelitian ini adalah induk jantan dan betina ikan mas koki (C. auratus), ikan patin siam ( $P$. hypophthalmus), ikan koi (C. rubrofuscus), ringer laktat, akuades, air, sari buah kurma $(P$. dactylifera), $\mathrm{NaCl}$ Fisiologis, alkohol 70\%, kertas label, dan hormon reproduksi.

\section{Rancangan Penelitian}

Metode penelitian yang digunakan adalah metode eksperimental dengan Rancangan Acak Kelompok dengan tiga kelompok (ikan mas koki, ikan patin siam, dan ikan koi), empat perlakuan sari kurma $(0,5 \% ; 1 \% ; 1,5 \% ;$ dan $2 \%)$ yang kemudian dibandingkan dengan kontrol pada masing-masing kelompok.

\section{Prosedur Kerja}

Kolam yang akan digunakan sebagai wadah untuk pemeliharaan indukan disiapkan dan dibersihkan kemudian dikeringkan kemudian diisi dengan air bersih dengan ketinggian $3 / 4$ dari tinggi kolam. Indukan yang akan digunakan dilakukan induksi kematangan gonad terlebih dahulu dengan menggunakan ovaprim dengan dosis $0,5 \mathrm{ml} / \mathrm{kg}$ pada bagian intramuskuler. Perbandingan dosis hormon ovaprim dengan $\mathrm{NaCl}$ fisiologis adalah $1: 1$.

Indukan yang sudah diinduksi kemudian diseleksi dengan cara mengurut bagian perut menuju ke bagian lubang urogenital apakah mengeluarkan cairan putih kental. Untuk indukan betina dilakukan cara yang sama apakah mengeluarkan telur yang matang ditandai dengan telur berwarna oranye. Indukan yang sudah diseleksi kemudian di stripping untuk mengeluarkan sperma dan telur.

Tabung eppendorf $2 \mathrm{ml}$ diisi dengan $0.1 \mathrm{ml}$ sperma dari masing-masing ikan dan $0.9 \mathrm{ml}$ ringer laktat tanpa ditambah sari kurma dengan perbandingan sperma dan ringer laktat 1:9 dan disimpan dalam rak pendingin dengan suhu $5^{\circ} \mathrm{C}$.

Pembuatan ekstender kombinasi sari kurma dan ringer laktat disesuaikan berdasarkan perlakuan yang telah ditetapkan. Dosis sari kurma yang ditambahkan ke dalam larutan ringer laktat adalah $0.5 \%, 1 \%, 1.5 \%$ dan $2 \%$. Sperma dimasukkan ke dalam tabung eppendorf berisi ekstender dengan perbandingan sperma dan ekstender yaitu 1:9.

Induk betina ikan mas koki, patin siam dan koi yang telah dipilih diambil dari kolam kemudian ditimbang dan diukur berat dan panjangnya. Induk betina kemudian disuntik dengan ovaprim dengan dosis $0.5 \mathrm{ml} / \mathrm{kg}$ pada bagian intramuskuler. Perbandingan pengenceran hormon ovaprim dengan $\mathrm{NaCl}$ fisiologis adalah 1:1. Induk betina yang sudah disuntik dengan ovaprim kemudian di stripping ketika waktu latency time habis 9\&-12 jam setelah penyuntikan). Telur hasil stripping ditempatkan pada cawan arloji dengan jumlah yang sama untuk dilakukan fertilisasi. Dilakukan 
pengamatan pada telur yang terfertilisasi dan yang tidak terfertilisasi dan dihitung persentase telur yang terfertilisasi dan yang tidak terfertilisasi.

\section{Analisis Data}

Perhitungan motilitas spermatozoa dilakukan dengan dua cara yaitu secara massa atau kelompok dan individu. Perhitungan motilitas spermatozoa mengacu pada penelitian yang dilakukan oleh Sartoyo (2005), yaitu dengan menghitung secara visual dan hasilnya dinyatakan dalam perbandingan antara spermatozoa yang hidup dan yang mati. Satu tetes sperma diletakkan di atas objek glass dan ditutup dengan cover glass dan diamati di bawah mikroskop dengan pembesaran 400x, setelah mendapatkan fokus di bawah mikroskop kemudian diteteskan air untuk memicu motilitas spermatozoa.

Motilitas $=\frac{\text { Spermatozoa motil }}{\text { Total spermatozoa }} \times 100 \%$

Daya fertilisasi adalah kemampuan sel telur dan sel sperma untuk melakukan fertilisasi. Fertilisasi adalah proses bertemunya sel telur dan sel spermatozoa. Spermatozoa yang sudah diberi perlakuan kemudian dicampurkan dengan sel telur pada cawan petri. Telur pada masingmasing wadah diamati dengan ketentuan: telur berwarna putih bening (fertil), sedangkan yang berwarna putih keruh (infertil). Untuk menentukan nilai persentase laju fertilisasi menggunakan rumus:

$\mathrm{FR}=\frac{\mathrm{Tf}}{\mathrm{Nt}} x 100 \%$ atau $\mathrm{FR}=\frac{\mathrm{Tf}}{\mathrm{Tnf}} x 100 \%$ Keterangan :

FR : Daya Fertilisasi

Tf : Telur terfertilisasi

$\mathrm{Nt}$ : Jumlah telur yang ditebar

Tnf : Telur tidak terfertilisasi

\section{HASIL DAN PEMBAHASAN Motilitas}

Motilitas merupakan kemampuan gerak maju spermatozoa di dalam lingkungan zat cair. Pergerakan tersebut penting dalam membantu spermatozoa menembus sel-sel pelindung yang mengelilingi sel telur (Sujoko et al., 2009). Dosis kombinasi larutan sari kurma dan ringer laktat menunjukkan pengaruh pada motilitas dengan $\mathrm{F}$ hit $55,06>\mathrm{F}$ tab $1 \%$, kelompok ikan juga terlihat memberikan pengaruh pada motilitas dengan $\mathrm{F}$ hit $303,39>\mathrm{F}$ tab 1\%. Hal tersebut memberikan pengertian bahwa penyimpanan spermatozoa dengan menggunakan ekstender kombinasi larutan sari kurma dan ringer laktat bisa dilakukan meskipun ada penurunan daya motilitas pada spermatozoa ikan yang digunakan sebagai hewan coba (Gambar $1)$.

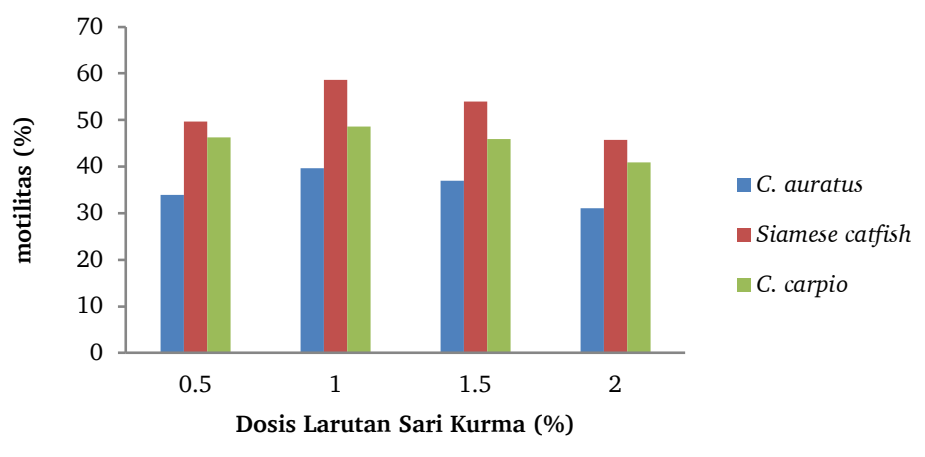

Gambar 1. Pengaruh ekstender terhadap motilitas sperma ikan koi, mas koki, dan patin siam.

Kemampuan spermatozoa untuk tetap menghasilkan daya motilitas didukung oleh larutan sari kurma dan ringer laktat pada kombinasi ekstender dalam pengawetan sperma. Sari kurma yang digunakan sebagai ekstender kombinasi mampu menyediakan energi selama pengawetan spermatozoa berlangsung, seperti yang dikatakan Adipu et al. (2011), bahwa di luar testis 
spermatozoa mampu memakai sumber energi dari luar untuk melanjutkan hidupnya. Bahan utama yang dipakai sebagai sumber energi dari luar adalah fruktosa yang akan diubah menjadi asam laktat dan energi dalam bentuk ATP dengan bantuan enzim fruktosilin. Pemberian larutan fruktosa sebagai pengencer untuk spermatozoa ikan dimaksudkan untuk memberikan energi dan nutrisi untuk spermatozoa ikan agar dengan energi yang berupa ATP tersebut dapat meningkatkan atau memperpanjang waktu motillitas dan viabilitas spermatozoa.

Menurut Arsetyo et al. (2012), nutrisi yang berupa glukosa dan fruktosa yang akan dipakai sebagai sumber energi yang berguna untuk menjaga kelangsungan hidup dan motilitas spermatozoa. Dalam keadaan normal energi yang dilepaskan dapat dipakai sebagai energi mekanik (pergerakan) atau sebagai energi kimiawi (biosintesis), jika tidak dipergunakan akan menghilang sebagai panas. Apabila persediaan energi habis, maka kontraksi fibril-fibril spermatozoa akan terhenti dan spermatozoa tidak bergerak. Untuk melangsungkan pergerakan kembali, ATP dan ADP harus disintesis kembali dengan penambahan gugusan fosforil yang membutuhkan sumber energi dari luar. metabolisme gula sederhana ini melalui respirasi sel spermatozoa menghasilkan ATP.

Nilai motilitas pada ikan Mas Koki mengalami penurunan paling banyak dibandingkan dengan spermatozoa pada kedua ikan yang lain meskipun tidak terlalu berbeda hal ini sesuai dengan penelitian yang dilakukan oleh Sunarma et al. (2008) bahwa pengawetan spermatozoa pada ikan Mas Koki dengan menggunakan glukosa sebagai bahan ekstender mengalami penurunan daya motilitas, dengan mengacu pada Babiak et al. (2001) bahwa ekstender berbahan dasar ion-ion garam lebih mampu mempertahankan motilitas daripada ekstender berbahan glukosa, sejalan dengan yang disampaikan oleh Sutoyo
(2000) bahwa media pengencer harus bersifat isotonik terhadap sperma.

Larutan pengencer yang bersifat hipotonik ataupun hipertonik akan mempengaruhi menergilisme spermatozoa. Khususnya sel bersifat semipermeabel, sehingga larutan pengencer baik yang bersifat hipotonik maupun hipertonik akan mempengaruhi transfer air melalui metabolisme sel dan menyebabkan rusaknya integritas sel yang kemudian menyebabkan kematian pada spermatozoa.

\section{Fertilisasi}

Pembuahan atau disebut juga dengan fertilisasi adalah proses bergabungnya inti sperma dengan inti sel telur dalam sitoplasma sehingga membentuk zigot. Pada dasarnya fertilisasi merupakan penyatuan atau fusi sel gamet jantan dan sel gamet betina untuk membentuk satu sel (zigot) (Affandi dan Tang, 2000).

Menurut Lesmana dan Dermawan (2001), masuknya spermatozoa ke dalam sel telur melalui mikrofil dan bergabung dengan inti sel telur merupakan proses pembuahan atau fertilisasi. Bersatu atau fusi dari inti sel jantan yang haploid (n) dan berada dalam sperma dengan inti sel telur yang juga haploid (n) ini akan menjadikan sel pertama somatis yang diploid (2n) dan disebut zigot. Proses ini akan memacu proses-proses selanjutnya yaitu tumbuhnya badan-badan atau kutub-kutub polar sel yang nantinya akan berkembang menjadi embrio.

Kombinasi ekstender larutan sari kurma dan ringer laktat tidak memberikan pengaruh terhadap daya fertilisasi pada spermatozoa kelompok ikan yang dicobakan dengan $\mathrm{F}$ tab 4,30<F Hit 5\%, namun kelompok ikan terlihat memberikan pengaruh terhadap daya fertilisasi dengan F Hit 33,97> F tab 1\%. Hal tersebut memberikan pengertian bahwa ekstender sari kurma dan ringer laktat sekalipun dapat dijadikan sebagai penyedia nutrisi untuk spermatozoa selama proses pengawetan namun tidak 
berpengaruh pada keberhasilan daya fertilisasi. Kelompok ikan koki mempunyai laju fertilisasi tertinggi $(97,23 \%)$ diikuti dengan kelompok patin siam $(88,66 \%)$, dan laju fertilisasi paling rendah dihasilkan oleh kelompok ikan koi yaitu 80,09\% (Gambar 2).

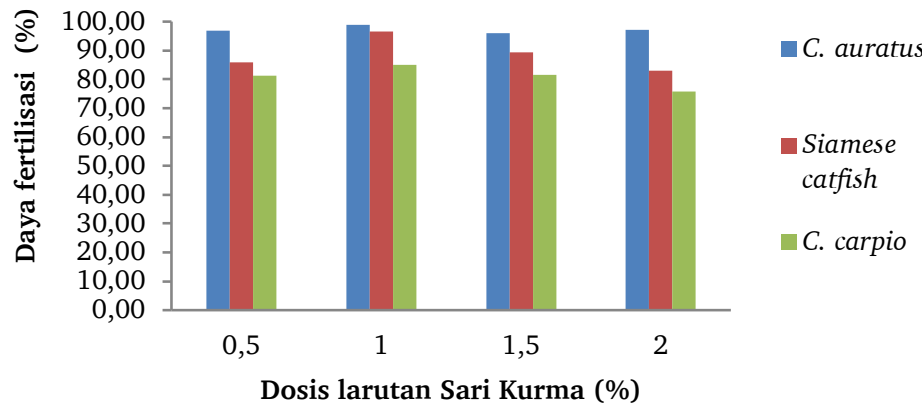

Gambar 2. Daya fertilisasi spermatozoa ikan koi, mas koki, dan patin siam yang telah diawetkan dengan ekstender kombinasi larutan sari kurma dan ringer laktat.

Nutrisi yang diberikan oleh larutan sari kurma berasal dari glukosa dan fruktosa sekitar 20-70\% (bobot kering). Sehingga buah kurma mudah dicerna dan cepat mengganti energi yang hilang (Retnowati dan Kusnadi, 2013). Menurut Hidayaturrahmah (2018), bahan utama yang dipakai spermatozoa sebagai sumber energi dari luar testis adalah fruktosa yang diubah menjadi asam laktat dan energi dengan bantuan enzim fruktolisin dalam proses glikolisis gula sederhana (monosakarida) yang dibutuhkan oleh spermatozoa untuk menjaga kelangsungan hidupnya. Kurniawan et al. (2013) menambahkan bahwa metabolisme gula sederhana ini melalui respirasi sel spermatozoa menghasilkan ATP.

\section{KESIMPULAN}

Berdasarkan penelitian yang dilakukan diperoleh kesimpulan bahwa ekstender kombinasi larutan sari kurma dan ringer laktat dapat memberikan pengaruh terhadap motilitas dan daya fertilisasi berbagai ikan air tawar. Meskipun mengalami penurunan motilitas namun daya fertilisasi yang ditunjukkan masih bisa mencapai 97,23\% sehingga ekstender kombinasi larutan sari kurma dan ringer laktat bisa digunakan sebagai penyedia nutrisi untuk spermatozoa selama proses pengawetan spermatozoa.

\section{UCAPAN TERIMA KASIH}

Peneliti mengucapkan terima kasih kepada Fakultas Perikanan dan Kelautan Universitas Brawijaya.

\section{DAFTAR PUSTAKA}

Adipu, Y., Sinjal, H.J. dan Watung, J., 2011. Ratio Pengenceran Sperma Terhadap Motilitas Spermatozoa, Fertilitas dan Daya Tetas Ikan Lele (Clarias sp.). Jurnal Perikanan dan Kelautan Tropis, 7(1), pp.48-55. https://doi.org/10.35800/jpkt.7.1. 2011.16

Affandi, R. dan Tang, U.M., 2000. Biologi reproduksi ikan. Fakultas Perikanan dan Ilmu Kelautan IPB, Bogor, 155.

Arsetyo, R., Abdulgani, N. dan Trisyani, N., 2012. Pengaruh konsentrasi larutan madu dalam $\mathrm{NaCl}$ fisiologis terhadap viabilitas dan motilitas spermatozoa ikan patin (Pangasius pangasius) selama masa penyimpanan. Jurnal Sains dan Seni ITS, 1(1), pp.E58-E63. DOI : 10.12962/j23373520.v1i1.917

Babiak, I., Glogowski, J., Goryczko, K., Dobosz, S., Kuzminski, H., Strzezek, J. dan Demianowicz, W., 2001. Effect of extender composition and equilibration time on fertilization ability and enzymatic activity of rainbow trout cryopreserved spermatozoa. Theriogenology, 56(1), 
pp.177-192. https://doi.org/10. 1016/S0093-691X(01)00553-2

Hidayaturrahmah, H., 2018. Waktu Motilitas dan Viabilitas Spermatozoa Ikan Mas (Cyprinus carpio L.) pada Beberapa Kosentrasi Larutan Fruktosa. Bioscientiae, 4(1), pp.9-18. https:// http://ppjp.ulm. ac.id/journals/index.php/bioscienti ae/article/view/158

Kurniawan, I.Y., Basuki, F. dan Susilowati, T., 2013. Penambahan air kelapa dan gliserol pada penyimpanan sperma terhadap motilitas dan fertilitas spermatozoa Ikan Mas (Cyprinus carpio L.). Journal of Aquaculture Management and Technology, 2(1), pp.51-65. http:// ejournal-s1.undip.ac.id/index.php/ jfpik

Lesmana, D.S. dan Dermawan, I., 2001. Budi Daya Ikan Hias Air Tawar Populer. Penerbit Swadaya.

Retnowati, P.A. dan Kusnadi, J., 2013. Pembuatan Minuman Probiotik Sari Buah Kurma (Phoenix Dactylifera) Dengan Isolat Lactobacillus Casei Dan Lactobacillus Plantarum [In Press April 2014]. Jurnal Pangan dan Agroindustri, 2(2), pp.70-81. https://jpa.ub.ac.id/index.php/jpa/ article/view/39

Salisbury, G.W., VanDemark, N.L. dan Lodge, J.R., 1985. Physiology of reproduction and artificial insemination of cattle (No. Ed. 2). WH Freeman and Company.

Sartoyo, 2005. Pengaruh Konsentrasi dan Suhu Penyimpanan terhadap Kualitas Sperma Ikan Mas Koki. Skripsi. Fakultas Kedokteran Hewan UNAIR. 58 hal.

Sujoko, H., Setiadi, M.A. and Boediono, A., 2009. Seleksi spermatozoa domba Garut dengan metode sentrifugasi Gradien Densitas Percoll. Jurnal Veteriner, 10(3), pp.125-132. http:// https://ojs. unud.ac.id/index.php/jvet/article/d ownload/3356/2396

Sunarma, A., Hastuti, D.W.B., Saleh, D.M. dan Sistina, Y., 2008. Kombinasi
Efektif Ekstender Dan Krioprotektan Pada Kriopreservasi Sperma Ikan Nilem (Osteochilus hasseltii Valenciennes, 1842). Jurnal Perikanan Universitas Gadjah Mada, 10(1), pp.76-84. https://doi.org/ $10.22146 /$ jfs.8931

Sutoyo, A. Peranan Bahan Pengencer Terhadap Penyimpanan Spermatozoa Sampai Penetasan pada Ikan Mas (Cyprinus carpio L.). Testis. Program Pasca Sarjana. Universitas Airlangga. Surabaya. 85 hal. 2000.

Widyaningsih, A., 2016. Pengaruh Konsentrasi Larutan Sari Kurma Dalam $\mathrm{NaCl}$ Fisiologi Terhadap Viabilitas Dan Motilitas Spermarozoa Ikan Nilem (Oseteocilus hasseltii Valenciennes) Selama Masa Penyimpanan (Doctoral dissertation, Universitas Brawijaya). 